\title{
Use of apple tree gene pool to create adaptive cultivars with high quality fruits
}

\author{
Nina Krasova ${ }^{1,{ }^{*}, \text { Laila } \text { Ikase }^{2} \text {, Dzintra Dekena }}{ }^{2}$, and Anna Galasheva ${ }^{1}$ \\ ${ }^{1}$ Russian Research Institute of Fruit Crop Breeding (VNIISPK), Zhilina, Oryol, Oryol region, Russian \\ Federation \\ ${ }^{2}$ Institute of Horticulture (LatHort), Graudu iela 1, Dobele, LV-3701, Latvia
}

\begin{abstract}
The apple tree gene pool was evaluated by resistance to adverse winter conditions based on the analysis of weather data for 50 years. $70 \%$ of winter-hardy and highly winter-hardy cultivars were revealed in the group of traditional local cultivars. Many local Central Russian cultivars are widely used in the breeding of new winter-hardy cultivars in central Russia, the Volga region, the Urals, Siberia, the Altai, the Far East and the south of the country. Positive results were obtained by using cultivars obtained from stepped crossbreeding, combining a complex of valuable qualities (winter resistance, immunity to scab, high qualities of fruits) in selection. On the basis of damaging factors' modeling, resistance to $-38^{\circ} \mathrm{C}$ temperature and resistance to frost after thaw were confirmed in most VNIISPK breeding cultivars; winter-hardy cultivars with a resistance threshold $-40^{\circ} \mathrm{C}$ : Vyatich, Orlovskiy partizan, Orlovskoye polesie, Zdorovye, Ministr Kiselev, Pamyat' Semakinu, Rozhdestvenskoye. Cultivars Idared, Golden Delicious, Granny Smith, Gala, Jonagold, Pink Lady, Fuji, Honeycrisp are recommended for use in breeding in combination with winter-resistant cultivars to create new high-quality apple tree cultivars with long keeping quality.
\end{abstract}

\section{Introduction}

The Federal Scientific and Technical Program for the Development of Agriculture for 2017-2025 has designated the development of the fruit industry through the creation and use of new technologies and cultivars. In terms of weather conditions' instability, the cultivar (cultivated variety) should combine productivity and high fruit quality and not depend on adverse factors [1].

At its huge length, Russia has territories with various natural and climatic zones and has the required natural and climatic resources for economically beneficial gardening management. The main suppliers of fruit products including apples is the European part of the country - the Southern and Central regions. Horticulture of the Ural-Siberian and Far Eastern zone is mainly represented by microclimatic territories suitable for apple trees' cultivation in the form of small-fruit semi-crops and new breeding, and European cultivars in layer form $[2,3]$. The apple tree (Malus domestica Mill.) is the main fruit crop in the

\footnotetext{
*Corresponding author: krasovang@vniispk.ru
} 
Central and Central Chernozem regions. Since ancient times, apples in Russia are very popular with consumers due to their availability, taste, cultivars' availability of different consumption periods and the long storage ability, rich biologically active substances composition. For successful gardening we need competitive, technological apple trees' cultivars with fruits of high commercial and consumer qualities, resistant to adverse biotic and abiotic factors, early maturing, yielding, mainly with a long consumption term, ensuring high production profitability $[4,5,6,7,8]$.

In the Russian Federation, due to old plantations' stubbing, fruit and berry plantations' area including seed crops decreased from 368 thousand hectares in 1990 to 116 thousand hectares in 2019 and remains about this the same level in 2020, with the continuation of stubbing, reconstruction and laying of intensive gardens. In 2019, in gardens of a new type, 918,2 thousand tons of seed fruits were harvested, i.e. the yield amounted to $79 \mathrm{cwt} / \mathrm{ha}$, which is almost 3 times more compared to 1990 due to industry intensification [9]. In recent years, Russia has seen an increase in consumption of fruits and berries and an increase in domestic commercial production. But providing the population of the country with their own fruits and berries remains insufficient and 70\% is replenished by imports [4].

The creation and selection of apple cultivars adapted to local conditions and capable of competing with imported ones in fruit quality is important in improving the efficiency and competitiveness of the horticulture industry. The foundation of apple breeding is a genetic collection of cultivars collected from various climatic zones of fruit crops' breeding. N. I. Vavilov attached great importance to the preservation and use of the source material diversity for breeding research [10].

The gene pool is a base for creating cultivars with adaptability at the level of old proven cultivars and with high fruit quality at the level of southern and western European cultivars. Increasing requirements for cultivars, changing climatic and economic conditions require continuous assortment upgrading through selection using complex sources of valuable traits.

For the middle horticulture zone of Russia, the main task of apple breeding is to create environmentally sustainable cultivars that combine high winter resistance with high commercial and taste qualities of fruits. The most preferable is to involve promising cultivars and forms of apple trees with low traits variability in changing external environment conditions in the selection.

The purpose of this work was to analyze the assessment results of modern approved and promising apple cultivars according to resistance to adverse winter conditions; To assess the use of traditional local apple cultivars, determine their role in the creation of new winter-hardy cultivars to improve the Russian assortment; Evaluate frost resistance of VNIISPK breeding apple cultivars.

\section{Materials and methods of research}

Research was carried out in VNIISPK apple trees plantings. Objects of study - varietal samples of apple tree gene pool of various genetic and geographical origin collected over a long period since 1972. Generally accepted methods of studying winter resistance in the field and the method of artificial freezing under controlled conditions in environmental test chamber ESPEC PSL-2KPH were used [11, 12].

Assessment of tissue and organ damage by low temperatures during winter was carried out on a 6-point scale, where 0 was no damage, 5 points - complete tree freezing.

In 2009 - 2020, the modelling of freezing conditions was carried out on the following main components of frost resistance:

$\mathrm{I}$ - resistance to early frosts (freezing mode: $-5^{\circ} \mathrm{C},-10^{\circ} \mathrm{C},-25^{\circ} \mathrm{C}$ ); 
II - the maximum level of frost resistance after conditioning (freezing mode: $-5^{\circ} \mathrm{C},-10^{\circ}$ $\left.\mathrm{C},-38^{\circ} \mathrm{C} ;-5^{\circ} \mathrm{C},-10^{\circ} \mathrm{C},-40^{\circ} \mathrm{C}\right)$;

III - resistance after thaws (freezing mode: $-5^{\circ} \mathrm{C},-10^{\circ} \mathrm{C},+2^{\circ} \mathrm{C},-25^{\circ} \mathrm{C}$ ).

Duration of exposure to temperatures: conditioning $-5^{\circ} \mathrm{C}$ (5 days) and $-10^{\circ} \mathrm{C}$ (5 days); temperature reduction of $5^{\circ} \mathrm{C}$ per hour; critical temperatures held up for 8 hours; thaw $+2^{\circ}$ $\mathrm{C}$ ( 2 days). Frosted branches were evaluated by tissue damage (by browning degree).

Statistical data processing was carried out by generally accepted methods (ANOVA), Version 22, SPSS) $[13,14]$ using the Microsoft Office Excel 2010 programm.

\section{Results and discussion}

For the middle zone of Russia, the main limiting factor of successful apple tree breeding is the combination of unfavorable factors of the autumn-winter period, often repeating harsh winters and lack of warmth in short growing season. The main factor determining the variety distribution range is the ability to tolerate unfavorable conditions of the winter period, autumn and spring frosts, sharp fluctuations in temperature, frosts after thaw and solar heating. The variety's winter resistance is determined by the genotype, but its manifestation largely depends on weather conditions and previous hardening degree.

Analysis of meteorological indicators for the period from 1970 to 2020 showed an unstable nature of weather conditions in the Oryol region (data from the VNIISPK weather station). There are sharp fluctuations in air temperature by year (Figure 1 and 2).

Over the 50-year period, the coldest were 10 winters with over $1000^{\circ} \mathrm{C}$ sum of average daily negative temperatures and a minimum air temperature below $-30^{\circ} \mathrm{C}$; average winter months air temperature in these years lowered to $-10.7^{\circ} \mathrm{C}$ with an average of $-8.4^{\circ} \mathrm{C}$ [15].

Winter thaws are particularly dangerous for fruit trees - especially long ones followed by a decrease in temperature; a sharp change in temperature during the day is also of negative influence as it helps to heat the bark and come out of the rest condition. Drastic fluctuations in temperatures contributed to bark burns formation on the stem and bases of skeletal branches, which has been observed in winters after prolonged thaws as trees emerge from deep rest and lose the ability of tissues to temper and retain frost-resistant state. American cultivars Delicious, Jonathan, Grimes Golden, McIntosh, Newtosh and others were badly affected in such winters. Freezing of apple trees in orchards of Orel, Kaluga, Tula, Moscow regions was revealed. The old trees of Pepin shafranny, Bel'flerkitayka, Pamyat' Michurina, Shafran-kitayka cultivars got significantly frozen, too.

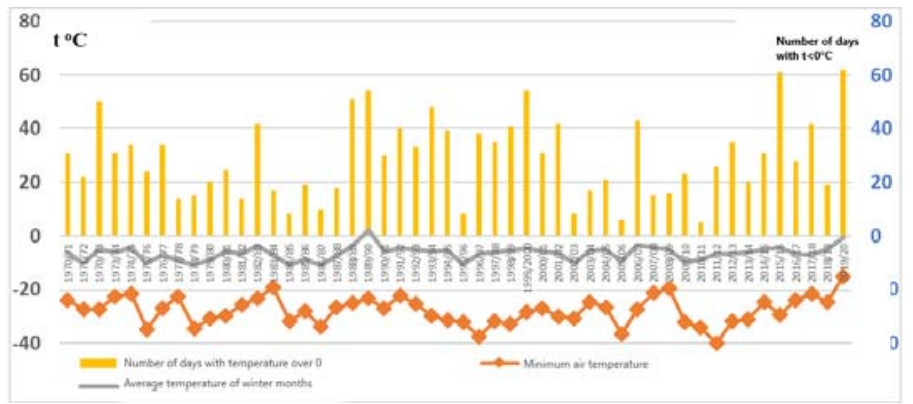

Fig. 1. Characteristics of winter conditions of 1970 - 2020 period (data from the VNIISPK weather station) 


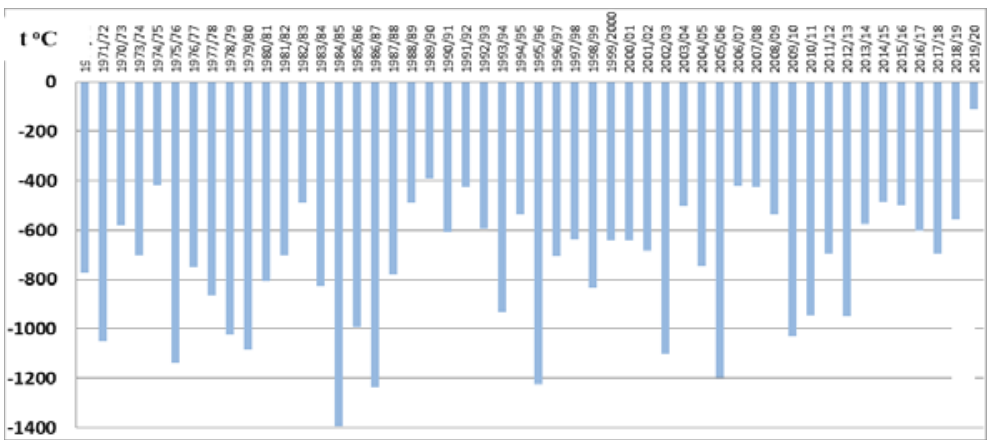

Fig. 2. Amount of average daily negative temperatures of winter conditions (December-February) of the $1970-2020$ period

The winter of 2005/06 was very cold in the middle zone of Russia. In Orel, the average air temperature in January was $-11.3^{\circ} \mathrm{C}$, in February $-13.2^{\circ} \mathrm{C}$, which is $4^{\circ} \mathrm{C}$ below normal. For a long period, the air temperature was kept at a level below $-20^{\circ} \mathrm{C}$, decreasing to $-36.5^{\circ}$ $\mathrm{C}$ in the air and to $-39.3^{\circ} \mathrm{C}$ on the snow surface. Negative effect of prolonged frosts manifested in bark damage on the stem and skeletal branches of cultivars Lobo, Melba, Aprel'skoye, Pepin shafranny, Izumitel'noye, Rossoshanskoye polosatoye in horticultural farms of Lipetsk region [16]; in Moscow region, significant damage was observed on cultivars Melba, Mantet, Lobo, Wealthy [17], in Tambov region, more than 35\% gardens perished that winter [18]. In VNIISPK plantings and Oryol region farms, the main zoned cultivars of apple trees overwintered safely - Common Antonovka, Bolotovskoe, Veteran, Zhigulevskoe, Kulikovskoe, Orlik, Orlovskoe polosatoe, Sinap orlovsky. The trees of European and American cultivars Voinesti, Linda, Realka, Florina, Chardin, Fantazja, Alkmene, Apollo, Champion did not withstand prolonged frosts and died.

A good check for apple trees' winter resistance was the period from 2010 to 2014 with thaw and subsequent sharp frosts and minimum air temperatures up to $-39.9^{\circ} \mathrm{C}$ (winter 2011/12). During these winters, the freezing of Idared, Democrat, Delikates, Liberty, Prima, Priscilla and other introduced cultivars increased. Deep thaws, sharp temperature fluctuations during the day caused great harm to fruit trees.

Over the past 50 years, the instability of winter conditions has been clearly traced. Cold periods alternate with warm ones. Only 12 winters with average winter month temperatures at or below normal were noted; the rest of the winters were warmer. Especially warm were winters with over 40 days thaws and the average winter months temperature not lower than $-5^{\circ} \mathrm{C}$ at a norm of $-8.4^{\circ} \mathrm{C}$. The winter of $1989 / 90$ was exceptionally warm with an average temperature of $2.3^{\circ} \mathrm{C}$ and a short-term decrease in air temperature to $-23.1^{\circ} \mathrm{C}$, as well as the winter of $2019 / 20$, when the minimum temperature did not fall below $-15^{\circ} \mathrm{C}$. The last 8 years (since 2013) winters have been warm with average monthly temperatures above normal and more days with positive temperatures. Analysis of weather conditions for 50 years shows that before there also were warm periods alternating with periods of sharp cold snaps. Therefore, in such unstable autumn-winter conditions, the role of the variety and the need for long-term assessment of apple cultivars' behavior in different changing conditions increases.

Long-term study of the gene pool on the main production and biological indicators allowed to estimate 850 apple cultivars by winter resistance in field and laboratory conditions (Figure 3). According to the assessment results of the types and nature of apple trees' damage in the field, cultivars were distributed in winter resistance groups according to their geographical and genetic origin.

Among the traditional and Ural-Siberian cultivars, $11.5-19.7 \%$ of highly winter-hardy cultivars with damage of not more than 1 point and 58.2-46.0\% (respectively) with minor 
damage were distinguished. High potential frost resistance when exiting deep rest state was often lost by various forms of crab apples, plum-leaved apples, as well as cultivars originating from the regions of the Urals and Siberia. So, Solntsedar, Ural bolshoy, Ural maslyanoy, Kommunarka cultivars were damaged by frosts in winters with unstable temperatures. Zorya and PA 29-1-1-63 were isolated from this group of cultivars; they showed high frost resistance both in winters with low temperatures and in winters with thaw. The involvement of these cultivars and forms in breeding makes it possible to consistently combine optimal levels of winter resistance on different components with other traits.

Highly winter-hardy cultivars (1.4\%) - Dekabrenok, Dessertnoe Isaeva, Zimneye, Korichnoye novoye, Mayak, Medunitsa and $42.8 \%$ winter-hardy cultivars were revealed in the group of public selection. Many breeding cultivars originating with participance of highly winter-hardy traditional or Ural-Siberian cultivars and forms, showed resilience sufficient for the conditions of the middle Russia horticulture zone. $19.7 \%$ of neighboring countries' cultivars are winter-resistant, including: Belarusian selection Alesya, Antey, Belorusskiy sinap, Belorusskoye malinovoye, Belorusskoye sladkoye, Imant, Kovalenkovskoye, Pamyat' Kovalenko, Pospekh, Syabrina; Ukrainian - Slava peremozhtsam, Donetskoye sladkoye; Lithuanian - Auksis; Estonian - Talvenauding, Tellissaare; Moldovan - Coremolda, Coredar. Latvian cultivars Ausma, Iedzenu, Daina, Ella showed stability at Antonovka level when modeling freezing temperature $-40^{\circ} \mathrm{C}$ in mid-winter and $-25^{\circ} \mathrm{C}$ after thaws [19].

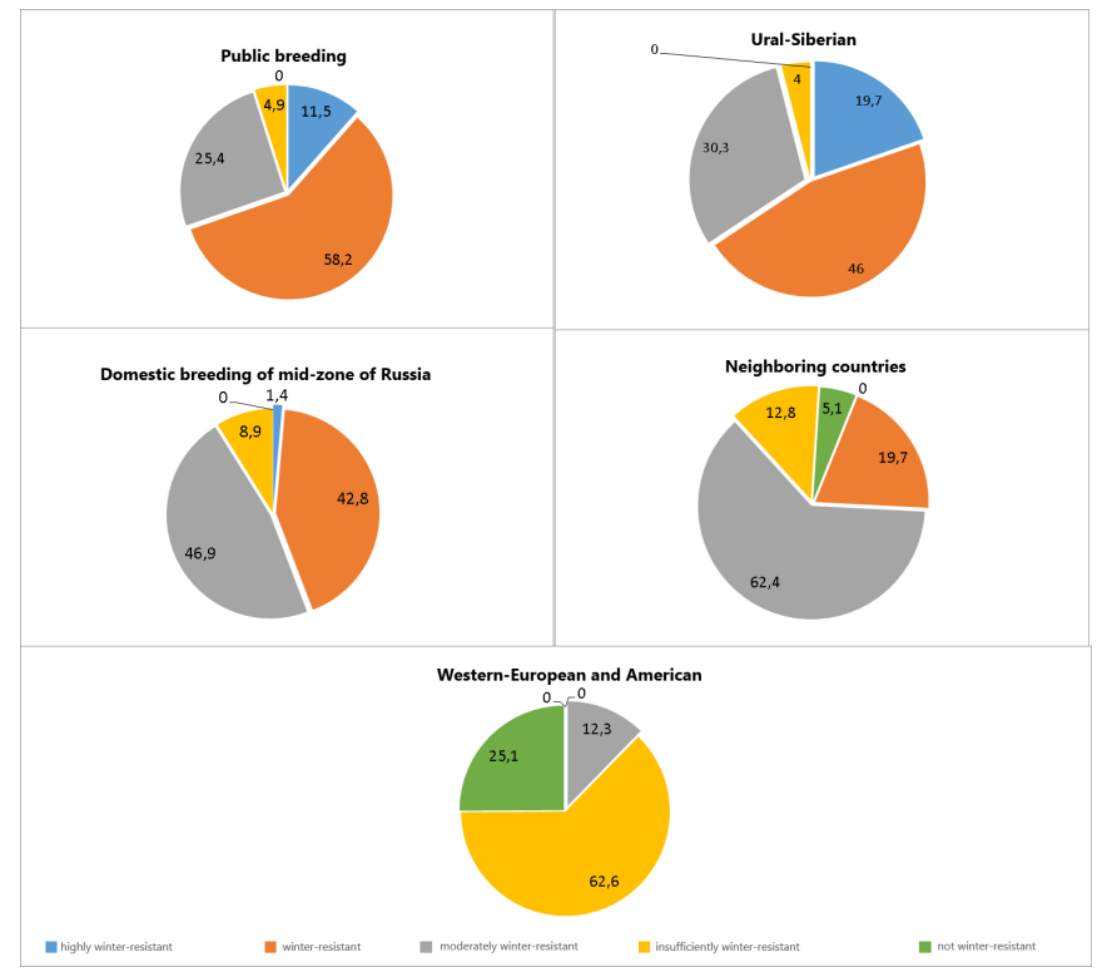

Fig. 3. Distribution of apple cultivars by winter resistance groups, $\%$ Public breeding $=$ traditional cultivars

In the group of American cultivars, only average winter-resistance was shown by $12.3 \%$ of cultivars - Lobo, McIntosh, Wealthy, Spartan. In recent years, the gene pool has been replenished with European, American, as well as New Zealand and Australian cultivars, 
which are still poorly studied, but some of them are approved for growing in the Central Chernozem region - Jonagold, Early Geneva, Honeycrisp (USA). For 20 years in the Baltic climate, Jonagold variety showed very low winter resistance, Geneva Early - medium, and Honeycrisp - good. The last 2 cultivars are planted in small quantities in commercial orchards of Latvia and Lithuania.

Cultivars of Finnish selection Samo, Sandra, Make in the conditions of the Oryol region withstood the coldest winters; with artificial freezing, they showed resistance to temperature decrease to $-40^{\circ} \mathrm{C}$ at Antonovka level and showed a high ability to maintain resistance to frost after thaw [20].

In conditions of winter temperatures' impermanence, the role of the variety considering its stability increases. Old Russian cultivars Naliv beliy (Alebastrovoye), Babushkino, Dobryy krest'yanin, Skryzhapel', Khoroshavka alaya, Papirovka (White Transparent) were well-known and widespread in Russia for a long time.

Cultivars Mal't, Mamutovskoye, Karmazinka - Old Russian cultivars and Putivka, Titovka - old Ukrainian cultivars were very popular in the past in Russia. Borovinka variety was widely distributed not only in Russia, but also in Western Europe under the name Duchess of Oldenburg.

In Russia, Western Europe and in America a variety of Ukrainian origin Aport Alexander had high popularity [21]. Some traditonal apple cultivars tested for adaptability by time, remain approved for growing and widely used in a number of regions of Russia Anis alyi and polosatyi, Korichnoye polosatoye, Common Antonovka, Papirovka, Osenneye polosatoye, the last three cultivars are approved in Belarus and Baltics as well.

Hardy, reliable local cultivars or landraces have been widely used as sources of stable winter resistance, early maturity, yield. Many local cultivars are widely used in variety breeding in central Russia, Volga region, Urals, Siberia, Altai, south of the country, Belarus, Baltic, and Scandinavian countries [2, 6, 22-27].

With the participation of Antonovka, cultivars were obtained having the same hardiness level, for the middle horticulture zone of Russia - Vishnevaya, Druzhnoye, Izbrannitsa, Imrus, Zdorov'ye, Letneye aloye, Martovskoye, Mezenskoye, Orlovim, Pamyat' voinu, Slavyanka, Chistotel. Antonovka also participated in the origin of the southern variety Renet kavkazskiy (Renet Simirenko $\times$ Common Antonovka).

Aport ASS variety was created with the participation of Bessemyanka Michurinskaya. Cultivars Zhigulevskoye, Zimnee polosatoye, Karlikovoye, Volzhanka, Volzhskaya krasavitsa, Letnee Dagestana, Renet Tatarskiy, Dubrovinka, Pamyat' Zhavoronkova, Podruga, Uralskoye rebristoye, Yubileynoe Shevchenko originated from Borovinka. With the participation of Papirovka, cultivars Lomonosovskoye, Rannee aloye were created; for harsh conditions of Siberia, cultivars Alenushka, Lada, Mana, and Krasnoyarskoye sladkoye were created on the Krasnoyarsk experimental station, on Sverdlovsk Experimental Station - Papiroyantarnoye, Uralskoye nalivnoye; for Buryatia Komsomolets Buryatii, Krasa Buryatii, Malinka, Pervenets Buryatii, and from Grushovka moskovskaya - Loyko, Siberskiy suvenir, Podarok BAMu.

According to the latest data, Borovinka (Duchess of Oldenburg) took part in the origin of the outstanding American variety Honeycrisp [28]. Seedlings of Antonovka variety were used in breeding in the Czech Republic - cultivars Angold, Produkta [29], in the USA Freedom variety [30], and Reglindis variety was created in Germany from Antonovka kamenichka seedlings [31]. In Finland, Antonovka crossing with Lobo resulted in cultivars Juuso, Konsta, and from Borovinka variety - Raike.

Traditonal cultivars showed good results in obtaining economically significant cultivars in the Baltic States. Antonovka variety was used to obtain Sidrunkollane Taliõun, Sügisdessert, Vahur and other cultivars in Estonia [32]. Osennee polosatoye (Streifling Herbst) variety was used to obtain Talvenauding, Tiina in Estonia, Noris - in Lithuania. 
Sipolins (Liflyandskoye lukovichnoye) variety was used to obtain Iedzenu in Latvia, which in further crossbreeding gave disease-resistant cultivars Daina, Laila, Madona, Monta, Pure Ametist, and in the second generation - Edite, Paulis. From cross Iedzenu $\times$ Slava peremozhcam the Eksotika variety was obtained, from its further hybridization - Dace, Roberts [33,34]. The original Slava peremozhcam variety was a result of Papirovka $\times$ McIntosh crossbreeding in Ukraine. Old Baltic cultivars Liivi Kuldrenett (under the name Renet Burkharda) and Suislepp were used in breeding in Kazakhstan; the resulting cultivars Rubin kazakhskiy, Zailiyskoye and Saltanat were included in the main assortment of Latvian gardens [35]. Liivi Kuldrenett and Suislepp were also used in breeding in Estonia, resulting cultivars - Kaja, Lembitu, Tiina, Katre, Kikitriinu [32].

In the first and next hybrid generations, traditional cultivars can give not only cultivars with high adaptation levels, but cultivars with high quality fruit.

With the participation of Skryzhapel - Kutuzovets, Bessemyanka Michurinskaya, Bolotovskoye, Nizkorosloye, Pamyat' Kedrina cultivars were created; with the participation of Anis - Anis Sverdlovsky, Berkutovskoye, Doch' Vagnera, Doch' Papirovki, Zvezdochka, Ijul'skoe Chernenko, Nasten'ka, Tenkovskoye.

Winter-hardy cultivars with a drooping crown (natural dwarfs) have been created in YuUNII when using Vydubetskaya plakuchaya in breeding - Arkaim, Bratchud, Kovrovoe, Kopeyskoye, Orskoye, Podsnezhnik, Orenburgskoe pozdnee, Prizemlennoe, Sokolovskoye, Fermer, Rumyanka sverdlovskaya, Trudovoye, Chudnoe. The following cultivars were obtained from Suislepp for the south of Russia Yuzhnoye and Letneye Dagestana.

Local cultivars rarely seen in gardens were also used in breeding: with the participation of Tsarskiy ship - Amurskoe urozhaynoe, Avgustovskoe dalnevostochnoe and Dalnevostochnoye rannee (Ranetka purpurovaya $\times$ Tsarskiy ship), as well as Barnaulskoe rannee (Amurskoe urozhaynoe $\times$ Uralskoe nalivnoe). Spartak, Udmurtskoe osennee cultivars originated from Sharopai.

When interbreeding local cultivars among themselves, hardy cultivars were obtained: for the middle horticulture zone of Russia - Tambovskoye (Sklyanka kurskaya $\times$ Belyi naliv), Renet tatarskiy (Borovinka $\times$ Renet povolzhskiy), Rtishchevskaya krasavitsa (Kandil-kitayka $\times$ Renet volzhskiy); for the Urals and Siberia - Yubileynoe Shevchenko $($ Ranetka Ermolaeva $\times$ Borovka), Dobrynya (Siberian crab-apple $\times$ Korobovka), Podruga (Borovinka $\times$ Ranetka khatanga 3499 (Siberian crab-apple $\times$ Korobovka), Junga (Nepobedimaya Grellya $\times$ Belyi naliv), Uralets (Voskovka $\times$ Anis rozovo-polosatyi), Divo (Ranetka skalenovka $\times$ Belyi naliv) and Sibirskiy suvenir (Grushovka moskovskaya $\times$ Siberian crab-apple); for southern Russia - Letnee Dagestana (Suislepp $\times$ Borovinka). Antonovka, Borovinka, Grushovka moskovskaya, Korobovka, Malinovka, Papirovka, Stakanchik - Central Russian traditional cultivars well-tolerated unfavorable conditions in the Southern Baikalia when growing in trailing form [3]. Local cultivars are used to enhance winter resistance in saturating inbreeding.

Winter-hardy apple cultivars obtained from repeated crossbreeding with local cultivars (F2, F3) are known and widely grown: Narodnoye - Belfler-Kitayka [(Belfler zheltiy $\times$ plum-leaved apple) $\times$ Papirovka], Pamyat' Kedrina - Kutuzovets (Skryzhapel $\times$ Renet Simirenko $) \times$ Orlik (McIntosh $\times$ Bessemyanka Michurinskaya), Uslada (Figure 4).

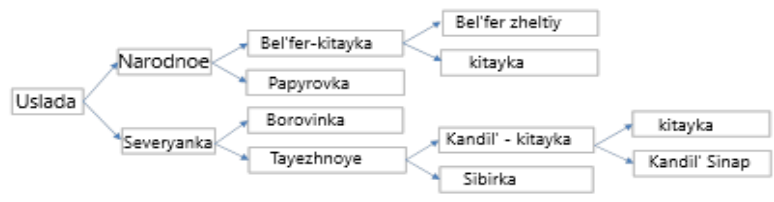

Fig. 4. Origin of Uslada variety 
In recent years, when creating scab-resistant apple cultivars, initial forms created by saturating inbreeding (F2, F3, F4) from local adaptive cultivars were attracted for interbreeding with immune forms, for example - Akademik Kazakov - Karpovskoye (Babushkino $\times$ McIntosh) $\times$ Releika), Munster - Bogatyr (Common Antonovka $\times$ Landsberger Renette) $\times$ hybrid 25-33 [Prima $\times$ Bessemyanka Michurinskaya (Skryzhapel $\times$ Bessemyanka Komsinskaya)], Flagman - Bogatyr (Common Antonovka $\times$ Landsberger Renette $) \times$ Skala [(Prima $\times$ Bessemyanka Michurinskaya), Tikhiy Don - 18-52- 39 (Korichnoye polosatoye $\times$ OR38T17) $\times$ Papirovka tetraploid, Vicor (Figure 5).

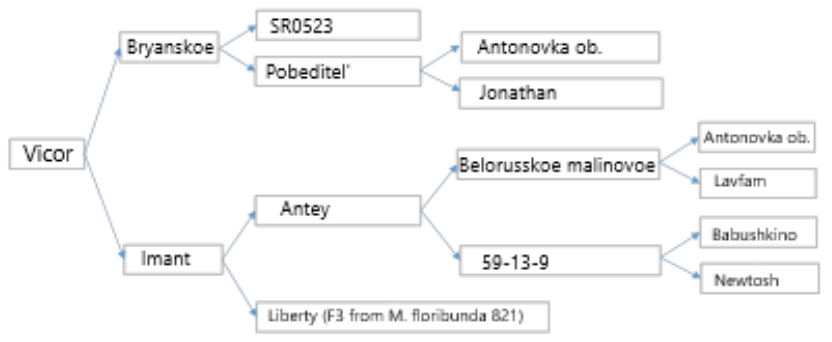

Fig. 5. Origin of Vicor apple variety

Quite good winter resistance of Korichnoe polosatoe variety was inherited in breeding cultivars with a wide usage range not only in the middle horticulture zone, but also in the gardens of the Ural region (Gornist, Kushnarenkovskoye osennee, Miasskoye, Simvol) [28].

Modeling of damaging factors allowed to identify the resistance potential of breeding cultivars which originated from Antonovka (Common Antonovka) traditional variety (Table 1). Cultivars of apple trees with resistance to simulated frosts $-38^{\circ} \mathrm{C}$ were identified. The resistance of buds, bark and wood at Antonovka level in cultivars Zdorovye, Imrus, Pamyat' Kovalenko, Svezhest' was revealed. Resistance of bark and wood to mid-winter frost was shown by Zaryanka, Orlovim, Orlovskiy pioner and Chistotel cultivars.

Table 1. Degree of freezing in different origin apple cultivars evaluated by modelling frost in the middle of winter

\begin{tabular}{|l|l|c|c|c|}
\hline \multirow{2}{*}{ Cultivars } & & \multicolumn{2}{c|}{$\begin{array}{c}\text { Degree of freezing, } \\
\text { score }\end{array}$} \\
\cline { 3 - 5 } & & \multicolumn{1}{c|}{ Origin } & \multicolumn{2}{c|}{ II component $(-5,-10,-$} \\
\cline { 2 - 5 } & & buds & bark & wood \\
\hline $\begin{array}{l}\text { Common } \\
\text { Antonovka }\end{array}$ & landrace & 0.6 & 0.4 & 0.7 \\
\hline Papirovka & landrace & 1.1 & 0.6 & 1 \\
\hline $\begin{array}{l}\text { Osennee } \\
\text { polosatoye }\end{array}$ & landrace & 1.4 & 1.0 & 0.4 \\
\hline Antey & Belorusskoye malinovoye (Antonovka $\times$ Lawfam) $\times 59-13-9$ & 1.4 & 0.4 & 1.4 \\
\hline Zaryanka & Antonovka krasnobochka $\times$ SR0523 & 1.2 & 0.1 & 1.2 \\
\hline Zdorovye & Common Antonovka $\times$ OR48T47 & 0.9 & 0.5 & 1.0 \\
\hline Imant & $\begin{array}{l}\text { Antey [Belorusskoye malinovoye (Antonovka } \times \text { Lawfam) } \times \\
59-13-9] \times \text { Liberty }\end{array}$ & 2.5 & 2.0 & 1.8 \\
\hline Imrus & Common Antonovka $\times$ OR18T13 & 0.9 & 0.3 & 0.1 \\
\hline Bogatir & Antonovka $\times$ Landsberger Renette & 1.6 & 1.5 & 1.5 \\
\hline Nadzeiny & $\begin{array}{l}\text { Antey [Belorusskoye malinovoye }(\text { Antonovka } \times \text { Lawfam) 59- } \\
13-9] \times \text { BM41497 }\end{array}$ & 1.1 & 1.3 & 0.6 \\
\hline Orlovim & Antonovka $\times$ SR0523 & 1.1 & 0.6 & 0.6 \\
\hline $\begin{array}{l}\text { Pamyat } \\
\text { Kovalenko }\end{array}$ & Common Antonovka $\times$ Lawfam) $\times$ BM41497 & 1.0 & 0.8 & 1.1 \\
\hline
\end{tabular}




\begin{tabular}{|l|l|c|c|c|}
\hline Pamyat Isaeva & Antonovka krasnobochka $\times$ SR0523 & 1.5 & 1.4 & 1.1 \\
\hline Pamyat Voinu & Wealthy $\times$ Common Antonovka & 1.7 & 1.5 & 1.3 \\
\hline Pervinka & Antonovka krasnobochka $\times$ SR0523 & 2.1 & 1.9 & 1.6 \\
\hline Pospeh & $72-11 / 94 \times$ Antey + BM41497 & 2 & 1.7 & 1.6 \\
\hline $\begin{array}{l}\text { Orlovskiy } \\
\text { pioner }\end{array}$ & Antonovka krasnobochka $\times$ SR0523 & 1.4 & 0.8 & 1.1 \\
\hline Suvorovets & Antonovka $\times$ Renet Simirenko & 2.5 & 2.0 & 1.5 \\
\hline Svezhest' & Antonovka krasnobochka $\times$ PR12T67 & 1.0 & 0.0 & 0.0 \\
\hline Chistotel & Common Antonovka $\times$ OR48T47 & 1.2 & 0.7 & 0.6 \\
\hline $\begin{array}{l}\text { Shafran } \\
\text { saratovskiy }\end{array}$ & Antonovka $\times$ Winter Goldparmäne & 1.7 & 1.4 & 1.4 \\
\hline
\end{tabular}

Note: the use of non-parametric Mann-Whitney U criterion showed the differences' insignificance in the frost damage degree in traditional cultivars compared with a group of new cultivars obtained with Antonovka participation at freezing temperature $-38^{\circ} \mathrm{C}($ level of significance $\mathrm{p}=0.05)$.

The study of frost resistance of young trees of VNIISPK cultivars in the very warm winter of 2020 showed buds resistance when exposed to temperature $-25^{\circ} \mathrm{C}$ after acclimation in early winter and damage intensification at the frost modeling $-40^{\circ} \mathrm{C}$ in the middle of winter. Bark, cambium and wood were resistant to frost $-40^{\circ} \mathrm{C}$ in cultivars Vyatich, Zdorovye, Ministr Kiselev, Pamyat' Semakinu, Rozhdestvenskoye with little damage up to 1.0 points and in cultivars Orlovskoye polesie, Orlovskiy partizan with damage not exceeding 1.7 points (Table 2). All studied cultivars showed resistance to frost up to $-25^{\circ} \mathrm{C}$ after simulated thaw (III component).

Table 2. Degree of tissue damage to apple trees' annual shoots by frost resistance components (2020)

\begin{tabular}{|c|c|c|c|c|c|c|c|c|c|}
\hline \multirow{3}{*}{ Cultivars } & \multicolumn{9}{|c|}{ Degree of freezing, score } \\
\hline & $\begin{array}{c}\mathrm{I} \\
\text { compone }\end{array}$ & \multicolumn{4}{|c|}{ II component $\left(-40^{\circ} \mathrm{C}\right)$} & \multicolumn{4}{|c|}{ III component $\left(-25^{\circ} \mathrm{C}\right)$} \\
\hline & buds & $\begin{array}{c}\text { bud } \\
\mathrm{s}\end{array}$ & $\begin{array}{c}\text { bar } \\
\mathrm{k}\end{array}$ & $\begin{array}{c}\text { cambiu } \\
\mathrm{m}\end{array}$ & $\begin{array}{c}\text { woo } \\
\text { d }\end{array}$ & $\begin{array}{c}\text { bud } \\
\text { s }\end{array}$ & $\begin{array}{c}\text { bar } \\
\mathrm{k}\end{array}$ & $\begin{array}{c}\text { cambiu } \\
\mathrm{m}\end{array}$ & $\begin{array}{c}\text { woo } \\
\mathrm{d}\end{array}$ \\
\hline $\begin{array}{l}\text { Antonovka } \\
\text { (control) }\end{array}$ & 0 & 1.7 & 0.8 & 0.5 & 0 & 0 & 0 & 0 & 0 \\
\hline Vyatich & 0.6 & 2.5 & 0 & 0 & 0.6 & 1.1 & 0 & 0 & 0 \\
\hline $\begin{array}{l}\text { Orlovskoye } \\
\text { polesye }\end{array}$ & 0.5 & 3.1 & 1.1 & 0.9 & 1.3 & 1.1 & 0 & 0 & 0 \\
\hline $\begin{array}{l}\text { Orlovsky } \\
\text { partizan }\end{array}$ & 0.7 & 2.3 & 1.7 & 1.5 & 0.8 & 0.4 & 0 & 0 & 0 \\
\hline Zdorovye & 0 & 2.7 & 0.8 & 0.5 & 1.0 & 0.3 & 0 & 0 & 0 \\
\hline Ministr Kiselev & 1.2 & 1.1 & 0.4 & 0.2 & 0 & 1.1 & 0 & 0 & 0 \\
\hline $\begin{array}{l}\text { Rozhdestvensko } \\
\text { ye }\end{array}$ & 0 & 2.1 & 0.6 & 0.4 & 0.2 & 0.8 & 0 & 0 & 0 \\
\hline $\begin{array}{l}\text { Pamyat } \\
\text { Semakinu }\end{array}$ & 0.7 & 2.3 & 0.6 & 0.4 & 0.2 & 0.1 & 0 & 0 & 0 \\
\hline $\mathrm{LCD}_{05}$ & 0.6 & 0.6 & 0.9 & 0.9 & 0.8 & 0.7 & & & \\
\hline
\end{tabular}

High bark resistance at freezing temperature $-38^{\circ} \mathrm{C}$ was revealed in cultivars Bolotovskoye, Veteran and Svezhest', the latter preserved this bark resistance level even in modeling $-40^{\circ} \mathrm{C}$ temperature. Cultivars Bolotovskoye, Venyaminovskoye and Veteran had increased bark damage, but it was reversible (Table 3). Veteran, Orlik, Svezhest' cultivars' wood damage was small (1.0-1.8 points), but when the freezing temperature dropped to $40^{\circ} \mathrm{C}$ it increased to $2.3-2.8$ points. 
Table 3. Degree of VNIISPK breeding apple cultivars damages in the middle of winter $\left(-38^{\circ} \mathrm{C}\right.$ and $\left.40^{\circ} \mathrm{C}\right)$ and by frosts after thaw $\left(-25^{\circ} \mathrm{C}\right)$

\begin{tabular}{|c|c|c|c|c|c|c|c|c|c|}
\hline \multirow{3}{*}{ Cultivars } & \multicolumn{6}{|c|}{ II component } & \multirow{2}{*}{\multicolumn{3}{|c|}{$\begin{array}{c}\text { III component } \\
-5,-10,+2,-25^{\circ} \mathrm{C}\end{array}$}} \\
\hline & \multicolumn{2}{|c|}{ buds } & \multicolumn{2}{|c|}{ Bark } & \multicolumn{2}{|c|}{ wood } & & & \\
\hline & $\begin{array}{l}-5,- \\
10,- \\
38^{\circ} \mathrm{C}\end{array}$ & $\begin{array}{l}-5,- \\
10,- \\
40^{\circ} \mathrm{C}\end{array}$ & $\begin{array}{l}-5,- \\
10,- \\
38^{\circ} \mathrm{C}\end{array}$ & $\begin{array}{l}-5,- \\
10,- \\
40^{\circ} \mathrm{C}\end{array}$ & $\begin{array}{l}-5,- \\
10,- \\
38^{\circ} \mathrm{C}\end{array}$ & $\begin{array}{l}-5,- \\
10,- \\
40^{\circ} \mathrm{C}\end{array}$ & buds & bark & wood \\
\hline $\begin{array}{l}\text { Antonovka } \\
\text { (control) }\end{array}$ & 0.6 & 1.4 & 0.0 & 0.9 & 1.0 & 0.9 & 0.2 & 0.0 & 0.0 \\
\hline Bolotovskoye & 0.8 & 2.3 & 0 & 2.2 & 2.0 & 2.2 & 2.1 & 11 & 0.1 \\
\hline Veteran & 1.0 & 2.7 & 0.7 & 1.8 & 1.0 & 2.7 & 1.7 & 0.9 & 0 \\
\hline Svezhest' & 1.1 & 2.0 & 0.8 & 1.0 & 1.7 & 2.8 & 2.4 & 1.3 & 0.1 \\
\hline Sinap orlovsky & 1.9 & 2.2 & 1.3 & 1.3 & 2.0 & 2.1 & 1.5 & 0.8 & 0 \\
\hline Venyaminovskoye & 2.0 & 2.3 & 1.3 & 1.9 & 2.0 & 2.1 & 1.3 & 0.3 & 0.1 \\
\hline Orlik & 2.0 & 2.5 & 2.0 & 2.0 & 1.8 & 2.3 & 1.6 & 0.6 & 0.1 \\
\hline $\mathrm{LCD}_{05}$ & 0.3 & 0.4 & 0.4 & 0.5 & 0.3 & 0.4 & 0.4 & 0.5 & \\
\hline
\end{tabular}

Thus, most cultivars of VNIISPK breeding showed good tissue resistance to $-38^{\circ} \mathrm{C}$ winter frosts. Temperature of $-40^{\circ} \mathrm{C}$ is the resistance threshold for cultivars Zdorovye, Pamyat' Semakinu, Vyatich, Orlovskiy partizan, Rozhdestvenskoye, Ministr Kiselev, Orlovskoe polesie. Most cultivars tolerated frosts of $-25^{\circ} \mathrm{C}$ after thaw at the end of winter.

In order to meet consumer demand and ensure the cultivars' competitiveness, apple fruits must have attractive appearance and meet the tastes of buyers. In recent years, domestic cultivars faced difficulties to compete with surging imported apples. Apple cultivars Idared, Braeburn, Granny Smith, Gala, Jonagold, Pink Lady, Fuji, Honeycrisp, created in Australia, America, New Zealand, Japan, are superior to local cultivars by duration of fruit storage, commercial qualities, and some - by a pronounced sweet taste and crispy juicy flesh. These cultivars are well successful in Western Europe but are not suitable for the conditions of the middle horticulture zone of Russia, do not withstand periodically repeated harsh winters and lack of heat in a short growing season period. They may be recommended for use in breeding in combination with winter-proof local cultivars to create new high-quality apple cultivars.

\section{Conclusions}

As a result of long-term study of the VNIISPK apple tree gene pool on resistance to winter adverse conditions, about $70 \%$ of winter-resistant and highly winter-resistant cultivars were revealed in the group of traditional local cultivars. Many local Central Russian cultivars are widely used in breeding programs in various regions of Russia and abroad. Positive results were received using public breeding cultivars obtained from stepped saturating interbreeding in the creation of new cultivars with a complex of valuable qualities - winter resistance, scab immunity, high commodity, consumer qualities and long-term fruits' storage. Based on simulation of damaging factors, resistance to temperature decrease to $38^{\circ} \mathrm{C}$ and tissue resistance to frost $-25^{\circ} \mathrm{C}$ after thaw in most approved and promising cultivars of VNIISPK breeding was established. New winter resistant cultivars of VNIISPK 
breeding with a resistance threshold of $-40^{\circ} \mathrm{C}$ in the middle of winter were identified: Orlovskiy partizan, Orlovskoye polesie, Zdorovye, Ministr Kiselev, Pamyat' Semakinu, Vyatich, Rozhdestvenskoye. It was established that the winter resistance level of cultivars obtained with participation of traditonal cultivars does not differ significantly from the original forms, which is confirmed by statistical methods. Introduced cultivars of apple trees - Idared, Golden Delicious, Granny Smith, Gala, Jonagold, Pink Lady, Fuji, Honeycrisp showed weak resistance to low air temperatures in winter in the conditions of the middle horticulture zone of Russia, they lack heat and sunny days for the full fruit ripening. They are recommended to be used as initial forms to create new adaptive highquality apple cultivars.

\section{References}

1. A.A. Zhuchenko, Adaptive system of plant's breeding, 1, 708 (2001)

2. I.P. Kalinina, S.A. Makarenko, Achievements of science and technology in the Alta, 7, 9 (2013)

3. M.A. Rachenko, E.I. Rachenko, Actual questions of agrarian science, 4, 16 (2012)

4. I.M. Kulikov L.A Marchenko, Herald of the Russian Academy of Science, 87(2), 135 (2017)

5. I.M. Kulikov, I.A. Minakov, Horticulture and viticulture, 6, 40

6. E.N. Sedov, Breeding and new Apple cultivars, 5 (2011)

7. Federal scientific and technical program of agricultural development for 2017-2025, Collection of the legislation of the Russian Federation, 36(5421), 15467 (2017)

8. E.A. Egorov, Zh.A. Shadrina, G.A. Kochyan, I.N. Putilina. Selection and variety breeding of horticulture crops, 5(1), 28 (2018)

9. Official website of the Federal Government Statistical Service (2020) www.gks.ru

10. N.I. Vavilov, Selected works: Genetics and breeding, 557 (1966)

11. E.N. Sedov, N.G. Krasova, V.V. Zhdanov, E.A. Dolmatov, \& N.V. Mozhar, Program and methods of cultivar study of fruit, berry and nut crops, 253 (1999)

12. M.M. Tyurina, N.G. Krasova, S.V. Rezvyakova, N.I. Saveliev, E.N. Dzhigadlo, T.P. Ogoltsova, Program and methods of cultivar study of fruit, berry and nut crops, 74 (1999)

13. L.C. Hamilton, Statistics with STATA: Updated for Version 10, USA (2009)

14. Stata: Release 12, Statistical Software, College Station, TX: Stata Corp LP (2011)

15. Agroclimatic reference book (1972)

16. L.V. Grigoryeva, Horticulture and viticulture, 5, 2 (2007)

17. S.M. Medvedev, A.M. Mikheev, N.S. Kolpakov, I.A. Byadovskiy, P.A. Pokhodenko, Pomiculture and berry growing of Russia, 16, 77 (2006)

18. N.I. Savelyev, N.N. Savelyeva, A.N. Yushkov, Scientific publication Michurinsk center, 128 (2009)

19. N. Krasova, L. Ikase, I. Drudze, Agronomy Research, 18(S4), 2727 (2020)

20. N. Krasova. Z. Ozherelieva, A. Galasheva, Evaluation of Finnish apple cultivars (Malus domestica Borkh.). Agricultural and Food Science, 29(5), 515 (2020)

21. L.P. Simirenko, Pomology, 9 (1972) 
22. E.N. Sedov, Z.M. Serova, T. Yanchuk, M.A. Makarkina, S.A. Korneeva, Selection and variety breeding of horticulture crops, 7(1-2), 142 (2020)

23. Z.A. Kozlovskaya, Belarusian science, 457 (2015)

24. L. Ikase, R. Dumbravs, Biology, 2, 8 (2004)

25. L. Ikase, G.Lacis, Acta Horticulturae, 976, 69 (2013)

26. T. Kaukoranta, R. Tahvonen, A. Ylamaki, Agricultural and Food Science, 19(2), 144 (2010)

27. E.V. Ulyanovskay, E.A Belenk, BIO Web of Conferences, 25, 02001 (2020)

28. N.P. Howard, E. Weg van de, D.S. Bedford, C.P. Peace, S. Vanderzande, M.D. Clark, S.L. Teh, J.J. Luby, Horticulture Research, 4, 17003 (2017)

29. J. Blažek, J. Krelinova, Horticultural Science, 40(1), 8 (2013)

30. R.C. Lamb, H.S. Aldwinckle, D.E. Terry, Horticultural Science, 20(4), 774 (1985)

31. M. Fischer, Erwerbs-Obstbau, January, 50(2), 63 (2008)

32. K. Kask, Estonian Fruits, 212 (2010)

33. I. Drudze, Acta Horticulturae, 663, 895 (2004)

34. L. Ikase, Proceedings of International Scientific Conference Environmentally Friendly Fruit Growing 222: Fruit Science, 10 (2005)

35. E. Kaufmane, M. Skrīvele, L. Ikase, Proceedings of the Latvian Academy of Sciences, Section B, 71(3), 237 (2017) 